\title{
Review of the stratigraphic divisions of the kakortokite and lujavrite in southern Ilímaussaq
}

\author{
Henning Bohse and Steen Andersen
}

Kakortokite and lujavrite constitute the lower sequence of the stratified Ilímaussaq intrusion. Detailed field work in recent years has allowed the extension and refinement of the stratigraphy so that the idealised section from the south-east part of the intrusion (fig. 1) presents the current state of knowledge.

The kakortokite and lujavrite accumulated on the floor of the magma chamber which was probably formed by a major cauldron subsidence of at least $1600 \mathrm{~m}$. The exposed thickness of these two rock types is nearly $1000 \mathrm{~m}$; however the deeper levels and substratum are unknown. By the time the exposed part of the bottom sequence started to accumulate, the $800 \mathrm{~m}$ thick roof sequence had already solidified. At this time the magma chamber was roofed by naujaite and insulated from the wall rocks by a shell of early-formed marginal pegmatite (Andersen et al., 1981).

The general descriptions by Ussing (1912) and Ferguson (1964) serve as the basis for the description of these rocks. Later, Sørensen (1970) reviewed the rock types and overall structure of the intrusion, and more detailed discussion on the karkortokite is presented by Ferguson (1970) and Bohse et al. (1971). In the following pages definitions and descriptions of the different rock types and their relationships are given. This should help to remove the confusion that has existed about definitions and terminology in this geologically complicated part of the intrusion, and should further serve as a reference guide for future field work in the area.

\section{Structure}

Outcrops of the lower stratigraphic levels of the Ilímaussaq intrusion, represented by kakortokite and lujavrite, are largely confined to the south-east part of the intrusion (see geological map of the Ilímaussaq intrusion shown in the beginning of this volume). This is due to the combined effects of (a) different levels of erosion, (b) inward dip of layers towards the centre of the intrusion, and (c) a hinge-fault along the river Lakseelv with a 600-1000 m downthrow of the northern part (Ferguson, 1970; Bohse et al., 1971). The kakortokite thus forms the Kringlerne region, and the overlying aegirine lujavrites (fig. 1) are exposed at Laksefjeld and along the river Lakseelv. The highest member of the sequence - the arfvedsonite lujavrite - occurs mainly as an irregular, westward-dipping sheet on the plateau immediately to the west of Lakseelv valley. A later intrusive sheet of medium- to coarse-grained (M-C) lujavrite occurs in the Agpat area. A continuous vertical shell of marginal pegmatite enveloping the kakortokite-lujavrite sequence is not distinguished on the generalised map but is seen in the section (fig. 1).

Within the kakortokite-lujavrite sequence planar elements are distinguishable in three orders of magnitude: (1) boundaries between units, (2) phase layering in kakortokite and 


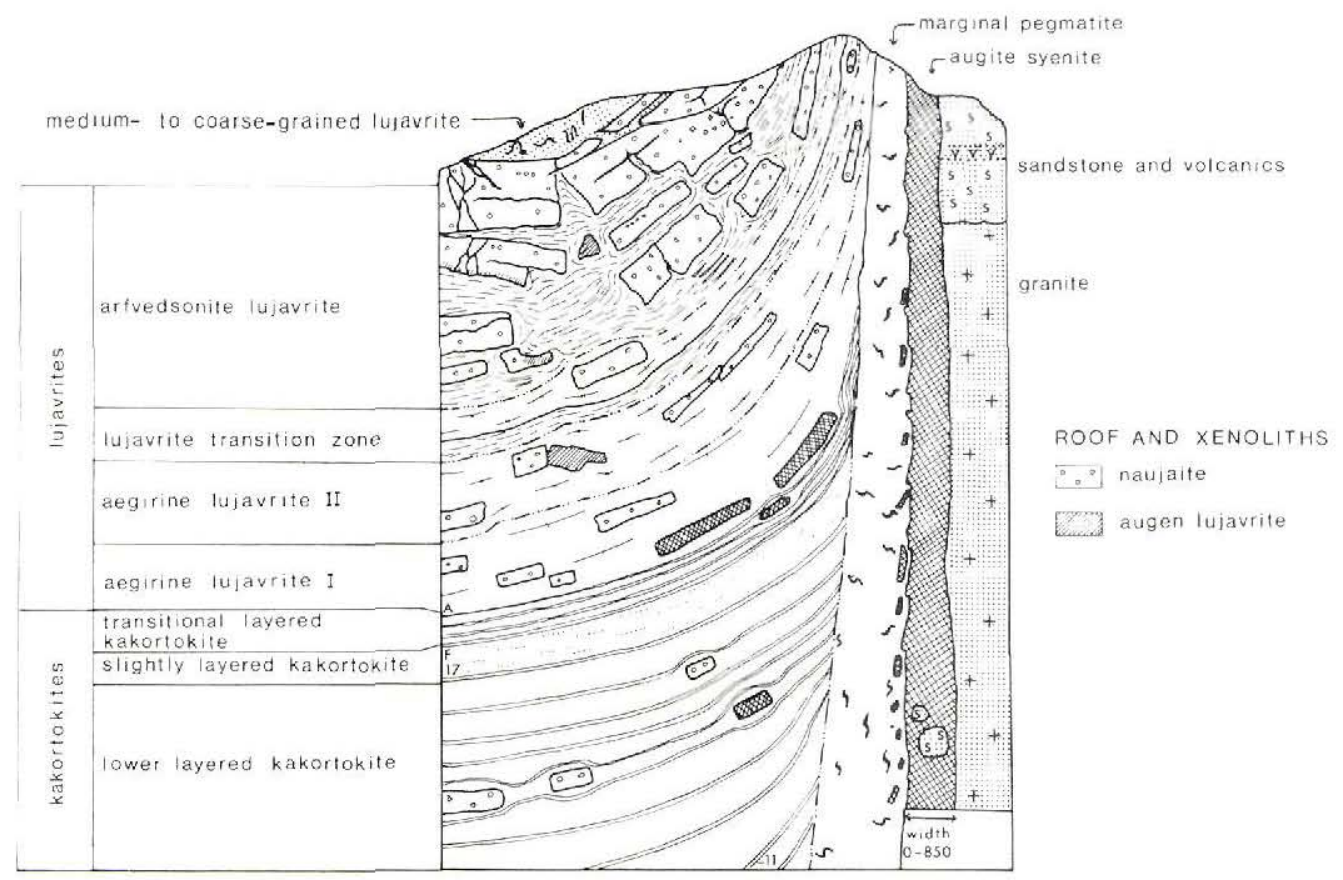

Fig. 1. Profile representing the lower sequence of the Ilímaussaq intrusion in the area from Agpat to Kringlerne.

some of the lujavrites, and (3) igneous lamination expressed by the orientation of tabular feldspar and acicular or prismatic mafic minerals. All planar elements are parallel at a single locality and can be combined to give the simple saucer-shaped pattern modelled in fig. 1. At the periphery of the intrusion the structures are steep to vertical while inwards the dip rapidly decreases so that the main part of the sequence has a general dip of $10-20^{\circ} \mathrm{NW}$.

The saucer-shaped structure is probably an original 'sedimentary' feature, and local, steep lamination around naujaite xenoliths shows that plastering of crystals against vertical walls was possible. Late-stage sagging may, however, also have played a rôle.

The content of roof xenoliths, especially naujaite, increases upwards through the sequence (fig. 1). Since the planar structures are strongly contorted around the xenoliths the overall structure becomes increasingly irregular upwards towards the naujaite roof. However, the overall structural continuity makes repeated intrusive events improbable in the main sequence. The later medium- to coarse-grained lujavrite is clearly a separate intrusion.

\section{Divisions within the kakortokite-lujavrite sequence}

The main minerals are essentially the same in all the rock-types described here. They are listed in Table 1, with comments. While the marginal pegmatite clearly stands out due to its contrasting structural position and texture, the stratified sequence is divided on the basis of the dominant mafic mineral and minor structural and textural features. 
Table 1. Mineralogy of kakortokite and lujavrite

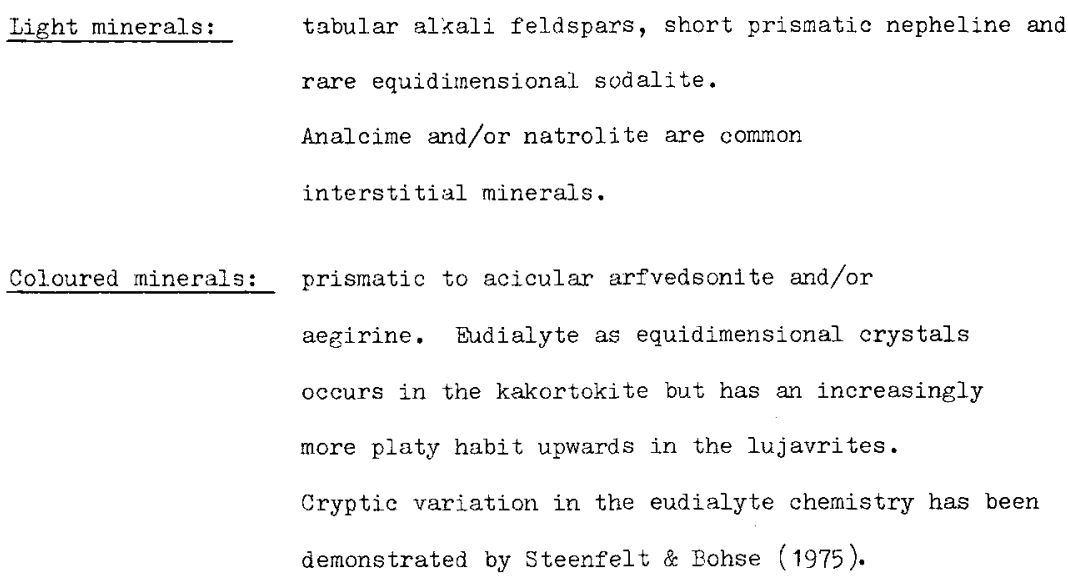

The grain size of the rocks diminishes upwards throughout the sequence.

The kakortokite is by definition a lujavrite in chemical as well as in mineralogical composition, but differs from other Ilímaussaq lujavrites in containing microcline perthite rather than the separate subsolvus laths of microcline and albite found in the lujavrites. In the kakortokites the main mafic mineral is prismatic arfvedsonite. The frequent occurrence of a striking layering made Ussing (1912) choose a new name 'kakortokite' for this rock type.

The stratified lujavrites, overlying the kakortokites, are divided into two main groups according to the prevalence of aegirine or arfvedsonite. In the lower half of the lujavrite series acicular aegirine is the only primary mafic mineral. The aegirine needles give the rock a pronounced green colour and 'green lujavrite' is often used synonymously for aegirine lujavrite. The aegirine lujavrite is further divided into two varieties (I and II), based mainly on minor structural and textural criteria which in the outcrop are expressed in colour and response to weathering. In the upper lujavrites arfvedsonite dominates over aegirine and gives the lujavrite a dark grey colour ('black lujavrite' = arfvedsonite lujavrite).

Medium-to coarse-grained lujavrite and augen lujavrite are found as intrusive sheets and inclusions, respectively, and hence are not direct members of the stratified sequence. The 
medium- to coarse-grained lujavrite (Sørensen et al., 1969) has affinity to pegmatites with regard to grain size and texture. Augen lujavrite appears as a hybrid rock with augens of sodalite (or pseudomorphs after sodalite) in a groundmass of lujavrite rich in aegirine.

\section{Description of rock units}

\section{Marginal pegmatite}

A continuous shell of coarse-grained rocks with closely spaced pegmatitic veins forms a margin around the kakortokite-lujavrite sequence (fig. 1). It separates the kakortokite and aegirine lujavrite from augite syenite to the west and south and from country rocks to the east. This shell was included in the kakortokite by Ussing (1912), but was treated as an independent unit by Bohse et al. (1971). The thickness of the marginal pegmatite decreases upwards from approximately $100 \mathrm{~m}$ at the lowermost exposed level (on the southern shore of Kangerdluarssuk) to $25 \mathrm{~m}$ at high levels in the Agpat area.

The marginal pegmatite is characterised by extreme heterogeneity, varying considerably in texture and mineralogy and including coarse kakortokite-like varieties and poikilitic naujaite-like varieties. Pegmatitic veins are found in increasing number towards the outer contact. Single pegmatites are a few centimetres wide. In the inner part of the shell they form an open net-veined pattern, but for the outer 5-10 $\mathrm{m}$ they are parallel with the contact. The main minerals are microcline, nepheline, sodalite, arfvedsonite, aegirine and eudialyte with rinkite, fluorite, astrophyllite and biotite as common accessories.

The outer contact against the augite syenite and the country rock is everywhere vertical, sharp and unchilled. The marginal pegmatite sends apophyses into the augite syenite, and rafts of syenite are found in the pegmatite close to the contact.

The inner boundary of the marginal pegmatite against the kakortokite is gradual over a couple of metres and the layering of the kakortokite becomes blurred towards the pegmatite. In contrast, the contacts against the aegirine lujavrites I + II are sharp. The lamination of the lujavrite steepens rapidly over the last hundred metres and is finally vertical and parallel to the contact with the marginal pegmatite (fig. 1).

The marginal pegmatite is interpreted as a border facies of the agpaitic magma. It is the earliest rock unit found in the section.

\section{Kakortokite}

The kakortokite forms the lowermost exposed unit of the stratified complex. It is a coarse-grained rock with pronounced feldspar lamination and extremely well developed gravity layering in the lower and upper parts.

The essential minerals are perthitic microcline (hypersolvus, tabular crystals), nepheline (stout prisms), arfvedsonite and aegirine (prisms and needles), and eudialyte (equidimensional crystals). Pure albite occurs as rims on the tablets of perthite and as small interstitial aggregates. It is late-magmatic together with sodalite, natrolite, acmite and katapleiite. Aenigmatite and rinkite are common accessories in the lower part.

Several xenoliths of augite syenite, naujaite and marginal pegmatite, and a single block of sodalite foyaite have been found in the kakortokite. The unit +3 (Bohse et al., 1971) in the lower part of the kakortokite series is particularly rich in xenoliths which was interpreted as 
the result of a single roof and marginal collapse. The xenoliths are frequently rimmed by a narrow pegmatitic zone with crystals of arfvedsonite and aegirine perpendicular to the contact.

The kakortokite is divided into three parts:

(1) lower layered kakortokite (LLK) about $200 \mathrm{~m}$ thick, overlain by

(2) slightly layered kakortokite (SLK) some $35 \mathrm{~m}$ thick, which again is succeeded by

(3) transitional layered kakortokite (TLK), which is about $40 \mathrm{~m}$ thick.

The lower layered kakortokite is the 'classic' type of kakortokite which occurs south of Kangerdluarssuk. It is a density stratified cumulate which has been subdivided into 29 layered units (numbered -11 to +17 upwards). The idealised layered unit is $10 \mathrm{~m}$ thick and consists of a three-layer sandwich. The base is an arfvedsonite-rich and perfectly laminated black kakortokite. Then follows saccharoidal red kakortokite rich in eudialyte. The unit finishes upwards with a white foyaitic to laminated layer dominated by nepheline and feldspar. The white layers are the dominant members of the units. The red and black layers are thinner and the red layers are frequently suppressed or absent. The regular layering becomes less distinct in the vicinity of the contact; thin graded layers (up to $15 \mathrm{~cm}$ thick) are separated by thicker layers of fairly homogeneous kakortokite. Current bedding and washout troughs filled with stratified rocks are also common in the vicinity of the contact. Similar structures are found near the steep contacts of the large xenoliths. Slump structures in the three units -6 to -4 indicate that at least $20 \mathrm{~m}$ of unconsolidated crystal mush existed at the bottom of the magma chamber at this stage of the crystallisation.

The slightly layered kakortokite conformably overlies the LLK to the north and north-east of Laksefjeld. This part of the kakortokite is virtually unlayered and only indistinctive dark layers are visible from a distance. The rock has the composition of an average kakortokite and appears grey. It is more fine-grained and has acicular mafic minerals in contrast to the prismatic crystals of the lower rocks.

In the overlying transitional layered kakortokite there is a return to the formation of black-red-white-layered units. The units are labelled F to A upwards. The grain-size decreases further in this division. The mafic minerals are acicular as in the SLK and the proportion of aegirine to arfvedsonite increases upwards in the sequence. The uppermost dark layer $\mathbf{A}$ has the composition of aegirine lujavrite (Demin, 1971), but as a member of a three-layer unit it is included in the kakortokite.

The white layer A grades over a distance of $4 \mathrm{~m}$ into typical aegirine lujavrite $\mathrm{I}$, i.e. the contact between kakortokite and aegirine lujavrite $\mathrm{I}$ is gradual and concordant.

\section{Aegirine lujavrite I}

Aegirine lujavrite I overlies the transitional layered kakortokite at Laksefjeld and along the Lakseelv valley from the head of Kangerdluarssuk fjord $4 \mathrm{~km}$ to the NE. This lower part of the aegirine lujavrites is about $80 \mathrm{~m}$ thick.

Aegirine lujavrite $I$ is a fine-grained rock with grain size decreasing upwards. It is strongly fissile, parallel to a distinct feldspar lamination and has needles of aegirine in the plane of lamination. Other cumulus minerals are equidimensional crystals of nepheline and eudialyte. These minerals occur in a matrix of interstitial natrolite and analcime. Feldspar-laths and aegirine-needles may be bent or broken against crystals of nepheline and eudialyte. Poikilitic crystals of arfvedsonite $0.5-3.0 \mathrm{~cm}$ in size are numerous at some localities. They may be 
partly or entirely replaced by aggregates of acmite. In the Kangerdluarssuk area some of the poikilitic crystals are rotated.

Weak to moderate rhythmic layering is visible in aegirine lujavrite I due to varying proportions of alkali feldspar and nepheline. A layered unit is about $10 \mathrm{~m}$ thick. It has a microcline-rich base which passes upwards into a nepheline-rich layer. The contact between the nepheline-rich layer and the following feldspar-rich base may be sharp but is more often gradual over a few centimetres. The susceptibility to weathering of the nepheline-rich part makes the layering stand out at a distance. Bailey et al. (1981) have described a rhythmic variation in the amount of eudialyte in aegirine lujavrite I from a borehole.

Numerous xenoliths are enclosed in aegirine lujavrite I. At Laksefjeld large inclusions of altered augite syenite cap the lujavrite with almost horizontal lower contacts. In the northwest wall of Lakseelv valley there are sharp-edged xenoliths of naujaite up to $200 \mathrm{~m}$ long but only $10-20 \mathrm{~m}$ in thickness. The contact between naujaite and lujavrite is usually sharp, and only minor signs of recrystallisation have been found. However, on the north bank of the mouth of Lakseelv the naujaite xenoliths are radically deformed and recrystallised. Minor inclusions are stretched to vein-like bodies a metre or more long and a few centimetres wide.

\section{Aegirine lujavrite II}

The transition from aegirine lujavrite I to the overlying aegirine lujavrite II is gradual over a few centimetres.

The main minerals are the same as in aegirine lujavrite I. Parallel laths of microcline and albite dominate the rock, but in strongly varying proportions. Aegirine occurs as very fine needles, nepheline as stout crystals and eudialyte as smaller hexagonal platy crystals with a clear brown colour. Primary sodalite is found in a few samples as crystals of about the same size as nepheline, but sodalite is more common as an alteration product of nepheline. The matrix consists of natrolite and analcime. Large crystals of arfvedsonite are frequent. The crystals may be poikilitic and irregular in shape or prismatic and sometimes arranged in radiating groups.

In aegirine lujavrite II all the xenoliths are naujaite. Unaltered and intensely recrystallised xenoliths are found side by side.

Aegirine lujavrite I and II have much in common, and in the field they are principally distinguished by textural features. Aegirine lujavrite II is more fine-grained than aegirine lujavrite I, and lamination and fissility, although pronounced, are not as extreme as in aegirine lujavrite I. Moreover aegirine lujavrite II has a lighter green colour due to the smaller size of the aegirine needles. The faint layering in aegirine lujavrite $I$ does not occur in aegirine lujavrite II. Under the microscope bent or broken feldspar laths and aegirine needles have not been observed. The two types behave differently to weathering. Aegirine lujavrite I splits into thin platy fragments; outcrops are often glacially polished with fine glacial striations preserved and usually covered by lichens. In contrast aegirine lujavrite II shows pronounced crumbling weathering and erosional surfaces are only rarely covered by lichens.

\section{Lujavrite transition zone}

Two layers, one of arfvedsonite lujavrite and one of aegirine lujavrite of type I, occur between the main aegirine lujavrite II and the overlying main arfvedsonite lujavrite, and 
Table 2. Transition zone between aegirine lujavrite and arfvedsonite lujavrite

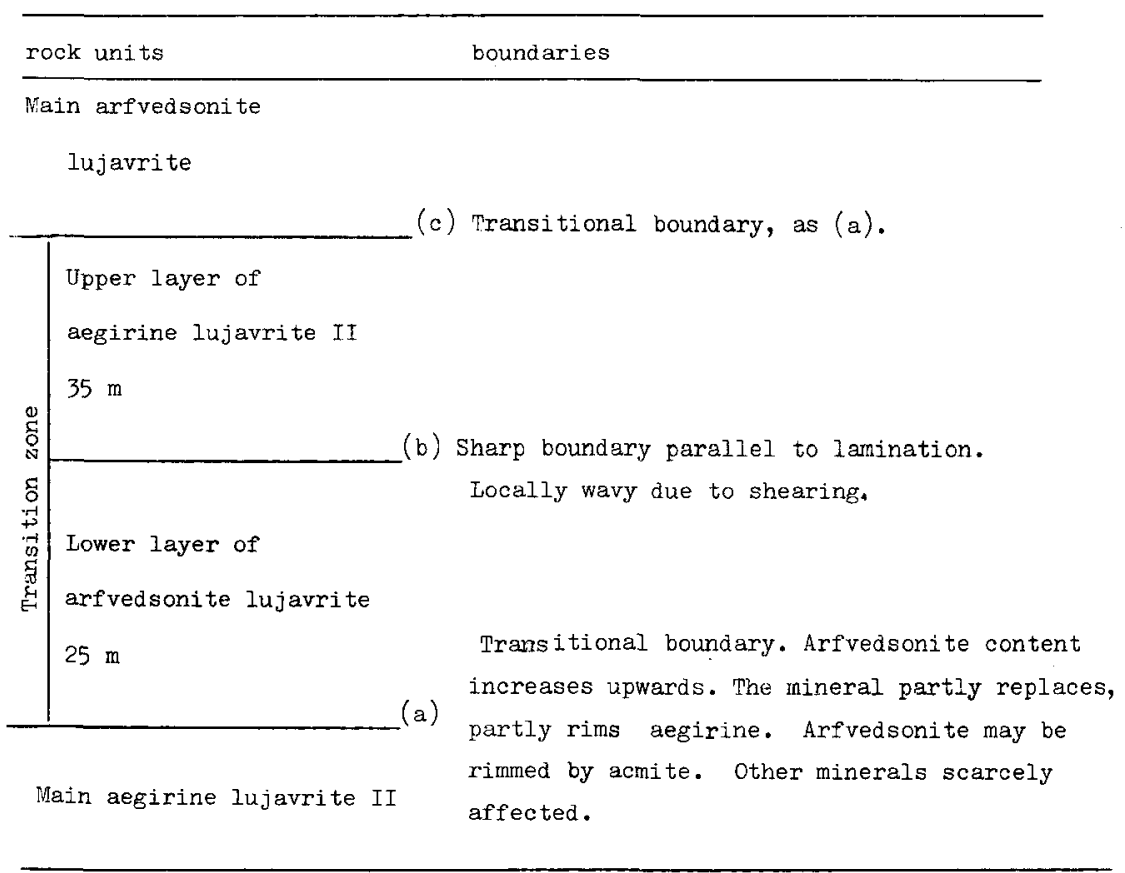

constitute the transition zone (Table 2). All boundaries are parallel to each other and to the lamination. They are thought to be depositional, although local, small-scale shearing may have affected the sharp boundary.

This transition has been mapped in the Agpat region and followed approximately $4 \mathrm{~km}$ to the south-east. In the Kangerdluarssuk region an entirely different evolution has been described by Demin $(1971,1972$; Demina, 1979).

\section{Arfvedsonite lujavrite}

The typical arfvedsonite lujavrite is a dark-grey fissile rock with the fissility mainly derived from the parallelism of tabular laths of albite and microcline. In hand samples the lamination is best seen in the planar arrangement of arfvedsonite needles, but these needles are interstitial to, and controlled by, the feldspars. This explains why lineations are rare to absent. Other main minerals in the typical arfvedsonite lujavrite are short prisms of nepheline and platy crystals of eudialyte. In most samples eudialyte is altered and replaced by aggregates of analcime with, among others, katapleiite, monazite and steenstrupine. The last mentioned minerals may also be primary. Late magmatic analcime is found in all samples, partly replacing the felsic minerals, and partly interstitial.

The thickness of the arfvedsonite lujavrite is about $150 \mathrm{~m}$. A more precise figure is meaningless as the upper boundary of the arfvedsonite lujavrite against naujaite is extremely irregular. Xenoliths of naujaite become increasingly close spaced upwards in the lujavrite, 
and in the upper part they change from isolated and settled rafts to massive naujaite intersected by sheets and irregular veins of lujavrite (fig. 1).

In the lower part of the arfvedsonite lujavrite several thin aegirine-rich layers reappear, reminiscent of the transition zone below. In the Agpat area a brown layer with arfvedsonite replaced by acmite can be followed for more than $1 \mathrm{~km}$ about $20 \mathrm{~m}$ above the contact to aegirine lujavrite II.

\section{Varieties}

In the mapping a number of structural and mineralogical varieties of arfvedsonite lujavrite are distinguishable. All varieties grade into each other and there is no sign of repeated intrusive events at any level in the main sequence.

The arfvedsonite lujavrite ranges between two prominent types:

Medium grey, hard lujavrite. Although well-laminated, this type is non-fissile and stands out in the outcrops as coherent benches. Hard lujavrite dominates in the Agpat area.

Brownish black and strongly fissile arfvedsonite lujavrite. This type weathers easily and crops out as heaps of broken plates. The main occurrence of brown lujavrite is on the high ground, about $700 \mathrm{~m}$ south-east of the bay of Tuperssuatsiait, and this is probably also the highest stratigraphic level of arfvedsonite lujavrite in the southern part of the intrusion. Between this area and the bay, the brown lujavrite occurs as naujakasite lujavrite with rhomboidal, silvery plates of naujakasite as a main mineral. The naujakasite lujavrite is the most radioactive of the lujavrites south of Tunugdliarfik. Villiaumite has not been found in drill cores of lujavrite south of Tunugdliarfik, but small cavities have been interpreted as imprints of dissolved villiaumite (Rose-Hansen, personal communication).

Further arfvedsonite lujavrite varieties are:

Banded arfvedsonite lujavrite. Inch-scale banding due to varying proportions of light minerals and arfvedsonite appears locally. The best developed banding is found near Agpat in a $125 \mathrm{~m}$ thick unit just above the lower contact of arfvedsonite lujavrite. A few much smaller occurrences are found further to the south-west at different stratigraphic levels.

The light-dark bands at these localities are parallel to the lamination. Single bands are persistent for several tens of metres, but branching of bands is common. Grading is not found. The banded appearence gradually fades away along the strike as well as upwards.

Lujavrites with light grey ellipsoids (spheroids of Sørensen, 1962). Light grey to brownish ellipsoids are in places common in arfvedsonite lujavrite and, if present, amount to a quarter to a fifth of the rock. The largest axis is usually $2-5 \mathrm{~cm}$ and parallel to the lamination. The ellipsoids may be eye-shaped with a dark core surrounded by a light grey rim. The ellipsoids are enriched in acmite (instead of arfvedsonite) and analcime. Analcime is the only felsic mineral in the cores, where it forms centimetre-sized crystals. The lamination marked by the mafic minerals passes through the ellipsoids and suggests the former existence of tabular feldspars. The nodular rocks are probably lujavrites in which the late magmatic reactions have taken place from regularly spaced centres.

\section{Medium- to coarse-grained lujavrite}

The medium- to coarse-grained lujavrite (M-C lujavrite) occurs south of Tunugdliarfik near Agpat. It is included in the aegirine lujavrite on the map of Ferguson (1964). The M-C lujavrite from this area was distinguished as 'schlieren lujavrite' by Andersen \& Bohse 
(1978), but it is now agreed that the rock is similar to the medium- to coarse-grained lujavrite at Kvanefjeld and this name is preferred (Sørensen et al., 1969).

The mineralogy of the $\mathrm{M}-\mathrm{C}$ lujavrite is largely similar to the main lujavrites. Feldspars, nepheline, eudialyte (or pseudomorphs) and mafic minerals dominate. Both aegirine and arfvedsonite-rich varieties exist with aegirine-rich types of largest occurrence in this area. Natrolite and analcime are interstitial. Steenstrupine is conspicuous due to the large size of the crystals, but the amount is hardly higher than usual for the lujavrite.

The following features of the $\mathrm{M}-\mathrm{C}$ lujavrite distinguish it from typical lujavrites and link it to pegmatites:

(1) The grain size is generally larger than in the other lujavrites, but varies within wide limits from medium grained to very coarse with feldspar and arfvedsonite crystals several tens of centimetres long. Hence the name.

(2) The crystals are non-orientated or found in radiating aggregates. Lamination is lacking. The M-Clujavrite shows crude, sub-horizontal jointing.

(3) The typical M-C lujavrite is composed of irregular, subparallel schlieren a few centimetres in width. The schlieren vary with regard to the proportion of minerals and the grain size and therefore in colour and degree of weathering. The varying grain size with coarse schlieren in a fine-grained matrix or vice-versa is very characteristic.

(4) Discrete pegmatites are common in this rock unit. Both planar types and ball-like masses are found. The pegmatites are dominated by white microcline laths which often form cruciform twins. Arfvedsonite occurs in large prisms and aggregates between feldspars. Natrolite and sodalite (a sea-blue variety) are interstitial. The pegmatites are rich in centimetre-sized crystals of steenstrupine.

The existing remnant of $\mathrm{M}-\mathrm{C}$ lujavrite covers about one square kilometre of the southeast coast of Tunugdliarfik. The lower contact dips to the north and is parallel to the hillside. The upper contact is eroded away, but it is supposed that the M-C lujavrite originally formed a sheet in naujaite at least $50 \mathrm{~m}$ thick.

The lower contact of the $\mathrm{M}-\mathrm{C}$ lujavrite is knife-sharp and accompanied by a few parallel sheets. It cuts naujaite as well as dykes of arfvedsonite lujavrite indicating that $\mathrm{M}-\mathrm{C}$ lujavrite was intruded as the youngest rock unit in southern Ilímaussaq. The time difference between the intrusion of $\mathrm{M}-\mathrm{C}$ lujavrite and the crystallisation of the higher levels of arfvedsonite lujavrite is probably small as the arfvedsonite lujavrite dykes attain an $\mathrm{M}-\mathrm{C}$ lujavritelike appearance upwards. In the model for the evolution of the agpaitic magma chamber, the M-C lujavrite is thought to crystallise from a late-stage, gas-rich magma. It was probably emplaced into a major fracture in the naujaite formed by the final subsidence of the roof. We have no hint about the place where the gas-rich magma pool formed before intrusion.

\section{Augen lujavrite}

The name 'augen lujavrite' is proposed for a special rock type found as xenoliths in lujavrite and as reaction zones around naujaite xenoliths. Two short dykes of augen lujavrite in naujaite have also been found.

The 'augens' consist of sodalite or, more often, of analcime pseudomorphs after sodalite. The grains are equidimensional to slightly elongated with a size of $3-5 \mathrm{~mm}$, that is equal to the dimensions of sodalite in naujaite. The groundmass is made up of two feldspars, nepheline and eudialyte wrapped between fine fibres of aegirine. Analcime frequently pseudo- 
morphs all light minerals. At some occurrences a slight parallelism exists in the platy feldspars and in the aegirine needles.

The augen lujavrite appears to be a hybrid between naujaite (represented by the sodalite augen) and lujavrite (the groundmass). The details of formation are not known. Some of the zones bound to naujaite are probably formed by simple recrystallisation with little influx of lujavritic material. Other occurrences, e.g. the dykes, have been entirely fluid and probably contained a larger amount of lujavritic magma. For these rocks an origin may be proposed along the boundary-surface between the early-formed naujaitic roof and the slowly evolving lower part of the magma chamber.

\section{Conclusions}

Recent field work has allowed the establishment of a detailed stratigraphy of the bottom cumulate part of the Ilímaussaq intrusion. This has shown that kakortokite and most of the lujavrites are crystallisation products of one magma batch, and has clarified the extent of the later discordant lujavrites in the southern part of the intrusion. It has provided a firm basis for refined work, both theoretical, field and laboratory, of which this volume already gives examples (Bailey et al.; Andersen et al.).

\section{References}

Andersen, S. \& Bohse, H. 1978: Field work on the kakortokites and lujavrites in the Ilímaussaq intrusion, South Greenland. Rapp. Grønlands geol. Unders. 90, 73-75.

Andersen, S., Bailey, J. C. \& Bohse, H. 1981: Zr-Y-U stratigraphy of the kakortokite-lujavrite sequence, southern Ilímaussaq intrusion (this volume).

Bailey, J. C., Bohse, H. \& Demina, A. 1981: Extension of Zr-REE-Nb resources at Kangerdluarssuk, Ilímaussaq intrusion (this volume).

Bohse, H., Brooks, C. K. \& Kunzendorf, H. 1971: Field observations on the kakortokites of the Ilímaussaq intrusion, south Greenland. Rapp. Grønlands geol. Unders. 38, $43 \mathrm{pp}$.

Demin, A. 1971: Detailed mapping in the southern part of the Ilimaussaq intrusion (Kangerdluarssuk fjord). Rapp. Grønlands geol. Unders. 35, 29-30.

Demin, A. 1972: Interpretation of field observations in the southern part of the Ilímaussaq intrusion, South Greenland. Rapp. Gronlands geol. Unders. 45, 33-34.

Demina, A. 1979: Field geology and petrography of the upper kakortokites and a section through the lujavrites of the Ilímaussaq intrusion, South Greenland. Unpubl. int. GGU rep., 52 pp.

Ferguson, J. 1964: Geology of the Ilímaussaq alkaline intrusion, South Greenland. Bull. Grønlands geol. Unders. 39 (also Meddr Grønland 72,4) 82 pp.

Ferguson, J 1970: The significance of the kakortokite in the evolution of the Ilímaussaq intrusion, South Greenland. Bull. Grønlands geol. Unders. 89 (also Meddr Grønland 190,1) 193 pp.

Sørensen, H. 1962: On the occurrence of steenstrupine in the Ilimaussaq massif, southwest Greenland. Bull. Grønlands geol. Unders. 32 (also Meddr Grønland 167,1) 251 pp.

Sørensen, H., Hansen, J. \& Bondesen, E. 1969: Preliminary account of the geology of the Kvanefjeld area of the Ilímaussaq intrusion, South Greenland. Rapp. Grønlands geol. Unders. $18,40 \mathrm{pp}$.

Sørensen, H. 1970: Internal structures and geological setting of three agpaitic intrusions - Khibina and Lovozero of the Kola Peninsula and Ilímaussaq, South Greenland. Can. Miner. 10, 299-334.

Steenfelt, A. \& Bohse, H. 1975: Variations in the content of uranium in eudialyte from the differentiated alkaline Ilímaussaq intrusion, south Greenland. Lithos 8, 39-45.

Ussing, N. V. 1912: Geology of the country around Julianehaab, Greenland. Meddr Grønland 38, $376 \mathrm{pp}$. 